\title{
Microfoundations of Organizational Routines and Capabilities on Demand of Designing Network Position through High Potential Acumen Leader on Absorptive Capacity
}

\author{
Palin Phoocharoon ${ }^{1}$ \\ ${ }^{1}$ NIDA Busines School, National Institute of Development Administration, Bangkok, Thailand \\ Correspondence: Palin Phoocharoon. E-mail: dr.palin@gmail.com \\ Received: September 8, 2017 \\ Accepted: September 22, 2017 \\ Online Published: November 28, 2017 \\ doi:10.5539/ass.v13n12p97 \\ URL: https://doi.org/10.5539/ass.v13n12p97
}

\begin{abstract}
Extending to explore how organizational antecedents affect absorptive capacity, this research proposed a theoretical model linking microfoundations of organizational routines and capabilities with network effects through high potential acumen leader (H-PAL). Drawing on a network effects of network position perspective with design thinking to enhance absorptive capacity, I argue that organizational design become a determinant factors on firm to produce more innovation on yielding better performance if leader has significance potential to grow in both the greater scale and scope of promising management skills. Building upon the dynamic capabilities view of the firm, the paper proposed an advance model with design thinking approach convincing that the value of conceptualizing and operationalizing network effects of network position via high potential acumen leader have open up new research interest that cut across traditional "micro versus macro" boundaries.
\end{abstract}

Keywords: High potential acumen leader, microfoundations of organizational routines and capabilities, network position, and absorptive capacity

\section{Introduction}

In recent years a great deal of scholarly attention have witnessed a contribution of absorptive capacity in innovation (Tsai, 2001), business performance (Lane, Salk, \& Lyles, 2001), interorganizational transfer of knowledge (Gupta \& Govindarajan, 2000), and interorganizational learning (Lane et al., 2001; Lichtenthaler, 2009). Given increasing interest in absorptive capacity, few have captured the holistic of multi-dimensionality of the concept. Despite, while most studies have focused on innovation that lead to competitiveness of the firm via absorptive capacity, organizational management antecedents, particularly organizational design, have been largely ignored (Lane, Koka, \& Pathak, 2006). Noticeable missing from research attention has been a potential of leadership, despite suggestions by creativity researchers that most scholars focus on greater effort on leadership approach rather than the potential level of such a leader.

In today's dynamic and increasingly hypercompetitive environment, firm aspire to achieve sustainability in their performance through frequent change, instead of rely on macrofoundations of organizational strategy and execution, microfoundations of organizational routines and capabilities is required. Felin, Foss, Heimeriks, \& Madsen (2012) realized that routines and capabilities have emerged as a central constructs in all field of management research. Particularly, it has also been closely linked to the interorganizational knowledge-based assimilation and transformation. Despite much progress has been made in understanding routines and capabilities, the interlinking microfoundations of these constructs have not received adequate attention (Felin et al., 2012).

The research proceeds as following; proposed a contemporary leadership paradigm that extending transformational leadership to high potential acumen leadership, integrating design thinking approach in complementary for leader to architect processes and structural fit with its organizational members to enhance their network effects of network position on recognizing and transforming valuable external knowledge to best interest of organization. Finally, the purpose is to enhance absorptive capacity to achieve frequent innovation to promote sustainable growth.

\section{Literature Review}

New Leadership Approach on Enhancing Microfoundations of Organizational Routines and Capabilities: High Potential Acumen Leader (H-PAL)

Over the last two decades, we have witnessed a clear consensus that transformational leadership represents the most active and effective form of leadership, a form in which leaders are closely engaged with follower and motivating them to outperform their potential. Bass $(1985,1990,1999)$ has theorized that transformational leadership comprises of four dimensions, intellectual stimulation, individualized consideration, idealized influence, and inspirational stimulation. All these capabilities relate directly to enhance firms encounter the difficulty by motivating employee to invest more on their work. 


\section{Microfoundations of Organizational Routines and Capabilities}

Cognition, action, and interaction within organization have presented as a central constructs in a field of management research. As recent growing body of research are highly influenced by innovation. Microfoundations of organizational competitiveness have drawn heightened attention form scholars and others (Lichtenthaler, 2009, Lewin, Massini, \& Peeters, 2011). The concept of microfoundations certainly is not new. It traditionally rest on sociology and philosophy in social theory, whereas early work used as a factor to explain organizational heterogeneity (Gavetti, 2005). Therefore, microfoundations of organizational routines and capabilities, specifically, referred to individuals, processes, structure, and interactions within and across components that contribute to the aggregation and emergence of the collective constructs (Felin et al., 2012).

\section{Design Thinking on Linking High Potential Acumen Leader (H-PAL) and Microfoundations of Organizational Routines and Capabilities}

\section{Shifting from Transformational leader to High Potential Acumen Leader}

Over the last two decades, we have witnessed a clear consensus that transformational leadership represents the most active and effective form of leadership, a form in which leaders are closely engaged with follower and motivating them to outperform their potential. Bass (1990) introduced transformational leadership concept for more than two decade. However, the majority of related leadership research has limited to three broad categories: non-transactional, transactional, and transformational. These categories describe leader behavior performance from passive-ineffective to active-effective (Avolio, 1999). Despite such existing leadership evidence that matters, researchers still need to know more about how leader cope with holistic dynamic change to produce upward mobility by influence each individuals and units in the workplace.

Across all three categories of leadership are characterized by the latitude of behavior characteristics. As Rubin, Munz, \& Bommer (2005) noted, transformational leader represents the most active and effective form in which leaders are effectively engage with the subordinates and motivate them to outperform their tasks and responsibilities. In addition, Poddakoff, MacKenzie, Moorman, \& Fetter (1990) described conceptualization of transformational leadership characteristics which included; articulating a vision of the future, fostering group-oriented work, setting high expectations, challenging followers' thinking, supporting followers' individual needs, and acting as a role model.

\section{Proposed Model}

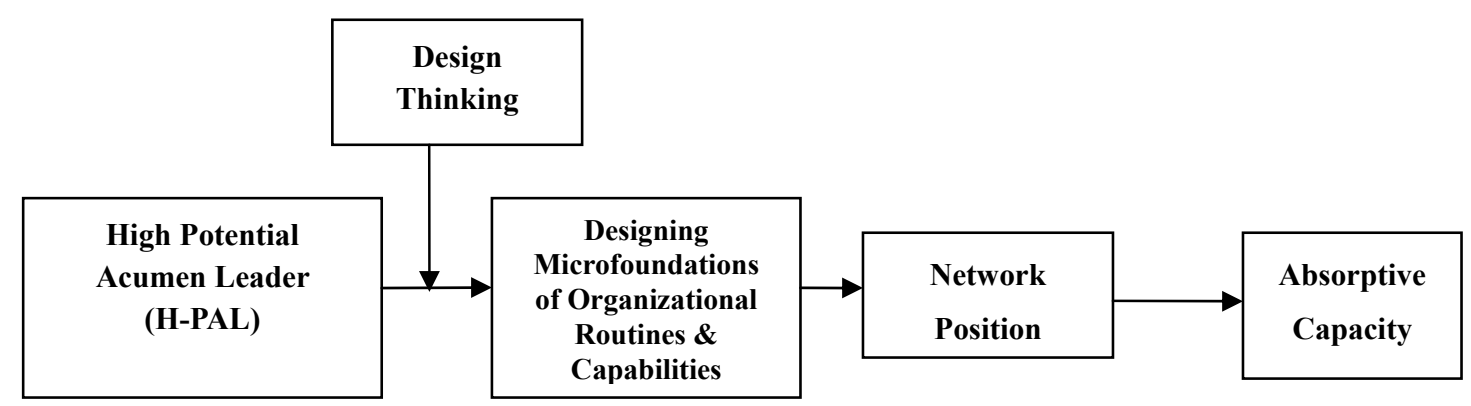

Theoretically, transformational leadership influences their subordinates by “broadening and elevating follower's goals and providing them with confidence to perform beyond the expectations specified in the implicit or explicit exchange agreement" (Dvir, Eden, Avolio, \& Shamir, 2002: 735). With respect to original personality traits and transformational leadership behaviors, one initial step forward explanation for those evidences support should be a leadership potential of designing management frameworks rather than emotional stability as usual. Thus, this paper take an initial step toward addressing this conspicuous oversight of a transformational leadership from Bass (1985) original concept which theorized that transformational leadership comprises four dimensions: intellectual stimulation, individualized consideration, charisma, and inspirational motivation.

\section{High Potential Acumen Leader (H-PAL)}

The extent studies indicated that narrowing leadership characteristic may be limited the usefulness of leadership capabilities. Therefore, a contemporary leadership discipline should shift its focus from leadership latitude or lateral abilities to longitude or vertical abilities to what extent define by leadership potential level.

One most business challenge is to ensure that firms ready to prepare "high potential" personnel that firms believe with trust that will become leaders. Setting a clear definition of "high potential leader" that mean someone will be able to succeed in a significant in bigger impact through their own ability to responsible greater scale and scope (Groysberg $\&$ Nohria, 2011). Thus, high potential acumen leader (H-PAL) is proposed. Whereas, high potential acumen leader is defines an extension of transformational leader with special attention to an overall potential to design individuals to fit with processes an interactions in suitable architect structure on enhancing better organizational routines and capabilities that be able to coup with current intense competitive market to ensure sustainable growth.

In sum, the alternative propose of new strategic leadership paradigm become an essential, whereas competitions are 
highly dynamic. The great insight was that firms compete not only with their direct rivals but also with their customer on creating more value and mutual benefits (Gavetti, 2011). To complete the mission, the entire value-chain activities must be proactively functional smartly. High potential acumen leader (H-PAL) is considered in the context of executing leading superior performance through their shrewdness of deriving insight. The proposed high potential acumen leader (H-PAL) might not only affect the development, operation, maintenance, and/or change of routines or capabilities, but also contribute to creativity capabilities (Vergne and Durand, 2010).

Establishment concept of acumen leader describe as one that has ability to make a good business judgement and quick decision, typically in a socio-economic benefits of the firm. A basic characteristics for assessing high acumen leadership potential extend from transformational leader are as follow; high power of associate thinking, derives insight, strongly influence collective organizational engagement, and leading congruence organizational direction. Proposing a new psychology of leadership is an attempt to make enormous progress and great strides poverty in order to lift up a quality and a standard of living of mankind through well-designed management in business activities for the next decades (Gavetti, 2011).

\section{Design Thinking}

Interest in how the application and practice of design might contribute to management and business is increasing exponentially. Empirically, there are variations within the theme, such as how design thinking might enrich strategic thinking, or how using common concepts in design practice can infuses a design of business practice (Martin, 2009). In this article, design thinking refers to the ability of leader to create appropriate processes, methods, approaches, structure, system and solutions that intelligence enough to ensure creative action (Brown, 2008, Martin, 2009). Moving beyond prior research by linking business leader and design thinking deserves an attention of researcher because thinking like a designer offers a way of framing management that go beyond pursuit of efficiency and help to ensure organizational innovation. Moreover, this allows us to separate theoretically and practically the influences of leadership and organizational performance.

\section{High Potential Acumen Leader (H-PAL) on Design Thinking Microfoundations of Organizational Routines and Capabilities}

Indeed, this study described how high potential acumen leader (H-PAL) design his thinking that offers a way of framing microfoundations affect routines and capabilities of firms. This article follows a working definition of microfoundations of organizational routines and capabilities which include constituent components (i.e. main effects)-individuals, processes, and structure; and interactions within and across components (i.e. interaction effects)the interactions of individuals, processes, and structures that contribute to the aggregation and emergence of the collective constructs (Felin, et. al.,2012: 1353). To describe a different way of design thinking, which would be a value of high potential acumen leader effectiveness would be reasonable to harness information, understanding, and managing emotional information in followers' thinking. Indeed, managing micro-level phenomena, specifically, individual, processes, and structure that have been played a central role in the origins of management theory, is required a correct path.

A complementary body of microfoundations lay as an important cause of emergence mechanism of processes and structure, particularly their interactions, through individual interest to absorb new external knowledge (Felin, et. al., 2012, Hodgson, 2012). Despite, the growing interest in microfoundations of organizational routines and capabilities, the lack of research regarding this issues with leadership potential have been largely ignored. The emphasis of this paper is placed on how leaders can influence their follower to interact effectively on a design thinking processes and structure on routines basis with relatively high attention on outperforming innovative task.

Even though, routine tasks establish automatic patterns of behavior, increasing task understanding and enriching organizational effectiveness required well-designed process, structure and its interaction. Therefore, high potential acumen leader (H-PAL) tentatively become the appropriate predictable variable that enable microfoundations absorptive capacity mechanism. In addition, high potential acumen leader with a high level of design thinking is likely to hamper the ability to design microfoundations factors ready for future innovation.

Proposition 1: High potential acumen leader will influence the well-designed microfoundations of organizational routines and capabilities on well-practice interaction for valuing new external knowledge for future innovation development.

Proposition 1a: Design thinking of high potential acumen leader mediates the effect of high potential leader acumen leader on well-designed for well-practice of microfoundations of organizational routines and capabilities.

Microfoundations of Organizational routines and capabilities and Network Effects of Network Position

While organizational routines and capabilities are theoretical linked with social network, these constructs may vary in multiple manifestations and focus on different phenomena. One implication of this heterogeneity is that many aspects of routines and capabilities require further explanation. Drawing on a network perspective on microfoundations of organizational routines and capabilities, one can argued that design organizational routines can enhance innovation toward better performance, if leader acknowledge network position of each organizational units recognizing and reveals its ability to acquire new external knowledge (Van de Ven, 1986). As Szulanski (1996) argued that without a 
unit's tie relationship, knowledge is hardly transfers to others unit within an organization. In addition, prior research on knowledge-based view of the firm has suggested that social networks facilitate the creation of new knowledge within organizations (e.g. Kogut \& Sander, 1992; Tsai, 2000). Therefore, social networks analyses can be partitioned into a number of conceptual and analytical categories in the proposed model.

Despite, networks effect and microfoundations of organizational routines and capabilities are particularly important in the study of organization management, the roles and responsibility defines the pattern of relationship and interactions that exist among actors in the processes have been surprisingly ignored. Social network methods are a mean of formally stating social properties and processes and rigorously defining management constructs, particularly on microfoundations of organizational routines and capabilities (Freeman, 1979).

Specifically, with an effective communication technology, it has been influenced the patterns of relationship that share engagement among each units in network significantly through designed network position. In which different network positions represent different opportunities of a unit to access new knowledge that is critical to create innovation (Tsai, 2001). Thus, the purpose of this study attempts to explore and to investigate the relationships between well-designed routines and capabilities at the micro-origins and the network effects through network position that has been directed by high potential acumen leader, particularly on design thinking approach.

Working on the behavioral theory of the firm directs attention to a potential a role of individuals in social network in explaining organizational outcomes. Indeed, Simon (1985) noted that research that linked these two concepts considerably ignore, particularly less focused on linking individuals' interest and cognitions to organizations' action on absorbing new external knowledge. The notion of bounded rationality serves as one starting point for new research contributions to leverage organizational learning (Lichtenthaler, 2009). Therefore, design thinking microfoundations of organizational routines and capabilities can enable units of different network position to gain access to new knowledge That is essential to create new innovative products and services.

Proposition 2: Design thinking of microfoundations of organizational routines and capabilities is consistent with network effects of network position to access new knowledge.

\section{Network Position and Absorptive Capacity}

In recent year researchers have used external knowledge to foster innovation and to enhance their performance (Zollo, Reumer, \& Singh, 2002). Lichtenthaler (2009) noted that developing new innovation depend on the ability to absorb knowledge of the firms. Prior research has drawn heightened attention from scholar and others. In particular, Cohen and Levinthal (1990) attempted to examine those capabilities and introduced absorptive capacity for more than two decades. From their seminal papers, which has been termed absorptive capacity. In response to the attention given to absorptive capacity, researchers have address various concepts associated with the emergence and implications of comprehensive absorptive capacity. This article addresses absorptive capacity as a firm's ability to utilize external knowledge through the sequential dimensions and processes on recognition, acquisition, assimilation, transformation, and exploitation (Cohen \& Levinthal, 1990, 1994, Zahra \& George, 2002, Lane, Koka, \& Pathak, 2006).

Exploratory learning, via recognizing, is considered as a starting point of learning through the establishment of acquiring external knowledge, and transforming acquired knowledge with their prior related knowledge in order to exploit it effectively on innovative matter (Zara \& George, 2002). Therefore, exploitative learning relates to both acquired knowledge and stock knowledge on ability of organizational members to perform tasks on routinely basis. The increased use of mutual learning and interunit cooperation is consistent with well-designed strong network effected through network position which promote organizational units and its members to work as a teams with a good interpersonal skills that be able to process and transfers complexity information and knowledge to new creative ideas.

Zahra \& George (2002) noted that knowledge recognition, transformation, and exploitation required sharing of relevant knowledge among members of the firm. Therefore, energizing multiunit within an organization to gain useful knowledge from each other is not only enhance firm to acquire more new external knowledge, but also provides opportunities to stimulate interunit to gain useful knowledge to enhance innovation (e.g., Kogut \& Zander, 1992; Tsai \& Ghoshal, 1998). Designing social networks through network position is likely to facilitate a creation of new knowledge within organization. Through different design network position, which depends on a potential of leader, represent a unit potential to connect to one another on recognizing and acquiring new external knowledge (Huber, 1991; Tsai, 2001). Therefore, firm that apply social networks interaction through design thinking network position will fuel strong connectedness on facilitating the flow of knowledge that allowing firm to assimilate, transform and exploit new knowledge for creative output. These observations suggest as the following:

Proposition 3: Applying network effects of network position are likely to enhance firm absorptive capacity, thereby the ability to create innovation is convincing.

\section{Conclusion and Practical Implications}

The paper provides the complementarity of learning processes through a role of new leadership approach on design thinking. High potential acumen leader is proposed along with comprehensive attention on designing microfoundations of organizational routines and capabilities with network effects of network position. The purpose is to explore an effective influence pattern to enhance absorptive capacity via high potential acumen leader. Regarding the proposed 
model, increasing exploratory, transformative, and exploitative of the firms via absorptive capacity requires the comprehensive design thinking on individuals, processes, structure, and their interaction. To actively increase absorptive capacity firm need to create an effective contextual antecedents that have significant influence on the emergence, operation, and effectiveness of high potential acumen leader.

From an antecedent perspective, it is clear that the design thinking capability of high potential acumen leader provide a significant form on organizing microfoundations of organizational routines and capabilities that draw on broadly accumulated knowledge within the domain of human capital, organizational capital and social capital. Thus, it would be reasonable to assume that while the antecedents of network effects of network position are likely to be somewhat reveals organizational ability relative strength in gaining access to new knowledge and leveraging useful knowledge proactively. Exploring new association path between leader and absorptive capacity through social networks is critical, particularly, when social network technologies can create strong network effects. Investigating design thinking on network position will provides useful information learning potential of its units on absorptive capacity on influencing the evolutionary path on an entire organization. As a starting point of developing such a mid-range theories on integrating macro-microfoundations of organizational routines and capabilities, pursuing this path of seeking will shed the light in a black box that has great potential to make significant contributions to management research.

\section{References}

Avolio, B. J. (1999). Full leadership development: Building the vital force in organizations. Thousand Oaks, CA: Sage.

Bass, B. M. (1985). Leadership and performance beyond expectation. New York: Free Press.

Bass, B. M. (1990). From transaction to transformational leadership: Learning to share the vision. Organizational Dynamics, 18(3), 19-31. https://doi.org/10.1016/0090-2616(90)90061-S

Bass, B. M. (1999). Two decades of research and development in transformational leadership. European Journal of Work and Organizational Psychology, 8, 9-32. https://doi.org/10.1080/135943299398410

Brown, T. (2008). Design thinking. Harvard Business Review. Cambridge: Harvard Business Press: June.

Cohen, W., \& Levinthal, D. (1990). Absorptive capacity: A new perspective on learning and innovation. Administrative Science Quarterly, 35, 128-152. https://doi.org/10.2307/2393553

Cohen, W., \& Levinthal, D. (1994). Fortune favors the prepared firm. Management Science, 43(10), $227-251$. https://doi.org/10.1287/mnsc.40.2.227

Dvir, T., Eden, D. Avolio, B. J. \& Shamir, B. (2002). Impact of transformational leadership of follower development and performance: A field experiment. Academy of Management Journal, 45, 735-744. https://doi.org/10.2307/3069307

Felin, T., Foss, N. J., Heimeriks, K. H. \& Madsen, T. L. (2012). Microfoundations of routines and capabilities: Individuals, processes, and structure. Journal of Management Studies, 49(8), 1351-1374. https://doi.org/10.1111/j.1467-6486.2012.01052.x

Freeman, L. (1979). Centrality in social networks: Conceptual clarification. Social Networks, 1, $215-239$. https://doi.org/10.1016/0378-8733(78)90021-7

Gavetti, G. (2011). The new psychology of strategic leadership. Harvard Business Review: Harvard Business Press. July-August; 118-125

Groysberg, B., \& Nohria, A. (2011). How to hang on to your high potentials. Harvard Business Review: Harvard Business Press. October 76-83.

Gupta, A. K., \& Govindarajan, V. (2000). Knowledge flows within multinational corporations. Strategic Management Journal, 21, 473-496. https://doi.org/10.1002/(SICI)1097-0266(200004)21:4<473::AID-SMJ84>3.0.CO;2-I

Hodgson, G. M. (2012). The mirage of microfoundations. Journal of Management Studies, 49(8), $1389-1394$. https://doi.org/10.1111/j.1467-6486.2012.01079.x

Huber, G. P. (1991). Organizational learning: The contributing process and the literatures. Organizational Science, 2, 88-125. https://doi.org/10.1287/orsc.2.1.88

Kogut, B., \& Zander, U. (1992). Knowledge of the firm, combinative capacities and replication of technology. Organization Science, 3, 383-397. https://doi.org/10.1287/orsc.3.3.383

Lane, P. J., Koka, B., \& Pathak, S. (2006). The reification of absorptive capacity: A critical review and rejuvenation of the construct. Academy of Management Review, 31, 833-863. https://doi.org/10.5465/AMR.2006.22527456

Lane, P. J., Salk, J. E., \& Lyles, A. (2001). IJV learning and performance. Strategic Management Journal, 22: 1139-1161. https://doi.org/10.1002/smj.206

Lewin, A. Y., Massini, S., \& Peeters, C. (2011). Microfoundations of Internal and external absorptive capacity routine. Organization Science, 22(1), 81-98. https://doi.org/10.1287/orsc.1100.0525

Lichtenthaler, U. (2009). Absorptive capacity, environmental turbulence, and the complementary of organizational 
learning processes. Academy of management Journal, $522(4), 846$. https://doi.org/10.5465/AMJ.2009.43670902

Martin, R. (2009). The design of business: Why design thinking is the next competitive edge. Cambridge: Harvard Business Press.

Podsakoff, P. M., MacKenzie, S. B., Moorman, R. H., \& Fetter, R. (1990). Transformational leader behaviors and their effects on followers' trust in leader, satisfaction, and organizational citizenship behaviors. Leadership Quarterly, 1, 107-142. https://doi.org/10.1016/1048-9843(90)90009-7

Rubin, R. S., Munz, D. C., \& Bommer, W. H. (2005). Leading from within: The effects of emotion recognition and personality on transformational leadership behavior. Academy of Management Journal, 48(5), 845-858. https://doi.org/10.5465/AMJ.2005.18803926

Simon, H. A. (1985). Human nature in politics: The dialogue of psychology with political science. American Political Science Review, 79, 293-304. https://doi.org/10.2307/1956650

Szulanski, G. (1996). Exploring stickiness: Impediments to the transfer of best practice within the firm. Strategic Management Journal, 17, 27-43. https://doi.org/10.1002/smj.4250171105

Tsai, W., \& Ghoshal, S. (1998). Social capital and value creation: The role of intrafirm networks. Academy of Management Journal, 41, 464-476. https://doi.org/10.2307/257085

Tsai, W. (2001). Knowledge transfers in intraorganizational networks: Effects of network position and absorptive capacity on business-unit innovation and performance. Academy of Management Journal, 44:996-1004. https://doi.org/10.2307/3069443

Van de Ven, A. (1986). Central problems in the management of innovation. Management Science, 32, $590-607$. https://doi.org/10.1287/mnsc.32.5.590

Vergne, J. \& Durand, R. (2010). The missing link between the theory and empirics of path dependence: Conceptual clarification, testability issue, and methodological implications. Journal of Management Studies, 47, 736-759. https://doi.org/10.1111/j.1467-6486.2009.00913.x

Zahra, S. A., \& George, G. (2002). Absorptive capacity: A review, reconceptualization, and extension. Academy of Management Review, 27, 185-203.

Zollo, M., Reuer, J. J., \& Singh, H. (2002). Interorganizational routines and performance in strategic alliances. Organization Science, 13, 701-713. https://doi.org/10.1287/orsc.13.6.701.503

\section{Copyrights}

Copyright for this article is retained by the author(s), with first publication rights granted to the journal.

This is an open-access article distributed under the terms and conditions of the Creative Commons Attribution license (http://creativecommons.org/licenses/by/4.0/). 